\title{
SIMULATION OF FLOOD PROGRESS ON THE RIVER GIDRA
}

\author{
${ }^{1}$ Tatiana PINDJAKOVÁ, ${ }^{2}$ Stanislav KELČíK, ${ }^{3}$ Andrej ŠOLTÉSZ \\ Department of Hydraulic Engineering, Faculty of Civil Engineering, \\ Slovak University of Technology, Radlinského 11, 81368 Bratislava 1, Slovakia \\ e-mail: ${ }^{1}$ tatiana.pindjakova@stuba.sk, ${ }^{2}$ stanislav.kelcik@stuba.sk, \\ 3 andrej.soltesz@stuba.sk
}

Received 20 January 2015; accepted 22 June 2015

\begin{abstract}
In Slovakia, the year 2011 can be characterized as dry with an irregular distribution of rainfall during the whole year. However, there were also some important hydrological events in form of flash floods. One of them a flash flood on the River Gidra, which passes the village of Píla situated below the Small Carpathians. A numerical simulation of this type of flood event was the main goal of the research in order to avoid the future devastating consequences of these kinds of floods. It was necessary to setup a mathematical model of the river using the HEC-RAS modeling tool to develop a correct evaluation of the flood course and to design appropriate flood protection measures, which will enable the interception of flood waves and to protect people and their property.
\end{abstract}

Keywords: Flood, village of Píla, Field-research, In-situ observation

\section{Introduction}

River flows are in the forefront of research on extreme hydrological conditions, further flood formations and possible threats to a country. A large storm swept over the Small Carpathians on June 7, 2011. It was connected with heavy rainfall, which caused torrential flooding of rivers with devastating consequences. There were no fatalities, in spite of huge damage, which included collapsed roads and bridges [1]. The village, which was the most affected by this flood, was the village of Píla, which belongs to the Červený Kameň micro-region (Fig. 1). During the field-research, important data concerning the River Gidra were collected and then used for reconstructing of the flood. The measurements were issued within the framework of a program encouraging young 
researchers at the Slovak University of Technology in Bratislava during the project 'Field-research and data collection to determine the interaction of the river and groundwater in the Červený Kameň micro-region'.

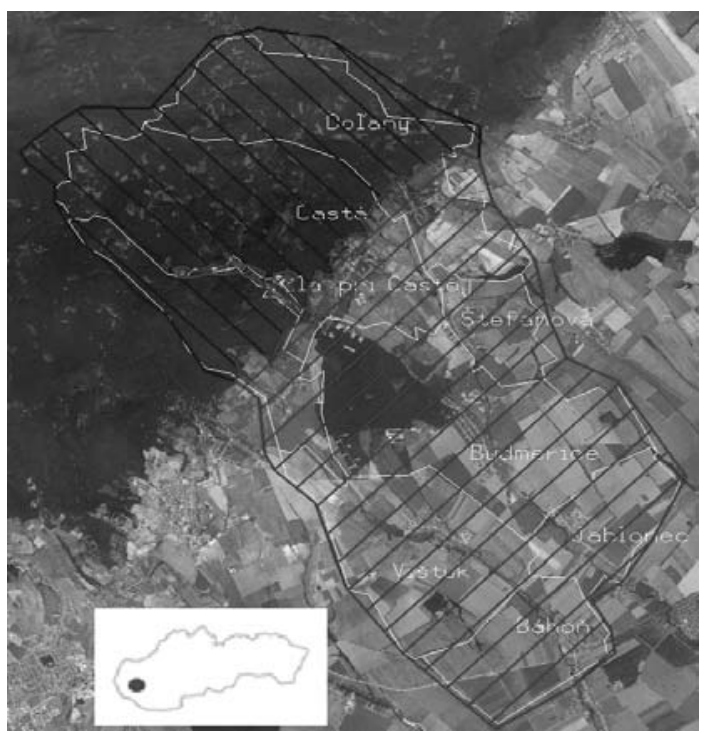

Fig. 1. Červený Kameň micro-region

\section{Description of the village of Píla}

The village of Píla (Fig. 2) belongs to the Pezinok district, which is located northeast of the capital of the Slovak Republic. The village stretches the length of a valley for about $2 \mathrm{~km}$. It is located in a protected area of the Small Carpathians and its altitude is $245 \mathrm{~m}$ a. s. 1 .

\section{Morphology of the River Gidra}

The River Gidra has a varied character along the part evaluated. Above the village of Píla it is a natural stream, but in the village local flow adjustments have been done. The river has the character of a prismatic concrete channel character below the village, and in the middle reach of the stream, regulated and unregulated sections have been changed [2]. Leica Viva GNSS devices and the Leica Sprinter digital leveling device were used during the field-research to determine the morphological characteristics of the River Gidra. To create an accurate numerical model it was necessary to acquire information about all the obstacles that are located in the river and about bridges, which could affect the water flow regime during extreme hydrological situations.

The first phase of the field-research was focused on collecting the morphological data of the River Gidra. This data is essential for setting up a 1D model by means of the 
HEC-RAS software package, for most properly fitted to the actual situation. In Fig. 3 the output from the HEC-RAS program is shown.

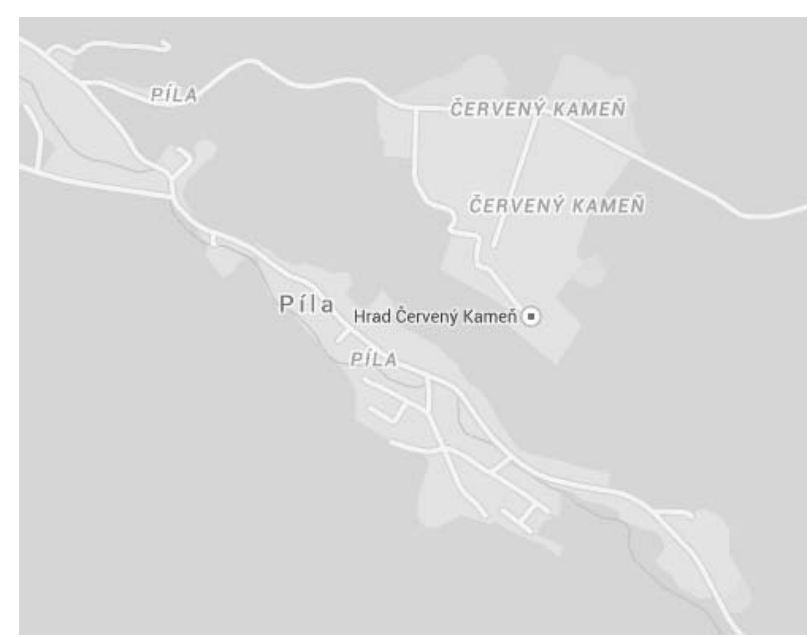

Fig. 2. The village of Píla

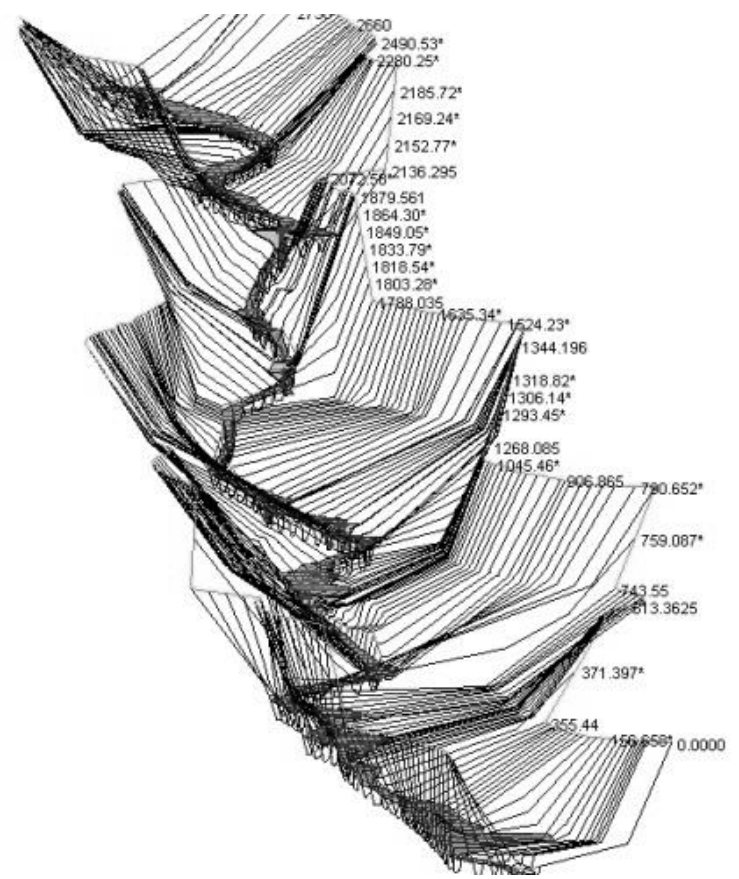

Fig. 3. Longitudinal cross-sections along the River Gidra at the village of Píla 


\section{Causes of the flash flood}

In general, impacts can be determined, which could accelerate surface runoff and result in flash flood in a basin during a specific hydro-meteorological situation. The causes of the flash flood always relate to the interaction among various conditions, and it is necessary to comprehensively take into account the river basin conditions [3].

\section{Meteorological situation}

An insignificant pressure field existed above Europe from June 5-6, 2011. Thunderstorms came from the west, and the highest rainfalls occurred during the afternoon in the Small Carpathians region. On Monday (June 6, 2011) rainfalls was concentrated in the area of the Small Carpathians, north of the town of Modra. On the eastern slopes of the mountain and at its foothills, from 50 to $100 \mathrm{~mm}$ of precipitation fell and in the most exposed locations, more over than $120 \mathrm{~mm}$ was observed. During the night from Wednesday to Thursday (June 8-9, 2011) and during Thursday it rained on the southern mountains of the Small Carpathians (more than $50 \mathrm{~mm}$ ). A precipitation value $60 \mathrm{~mm}$ is defined here as a value with the probability of occurring once every 4050 years, and a precipitation amount of $100 \mathrm{~mm}$ or more can be classified as a value with the probability of occurring once in 50 years [1].

The spatial distribution of the daily rain on June 7, 2011 in the area of the Small Carpathians was performed by the Slovak Hydro-Meteorological Institute (Fig. 4) $[4],[5]$.

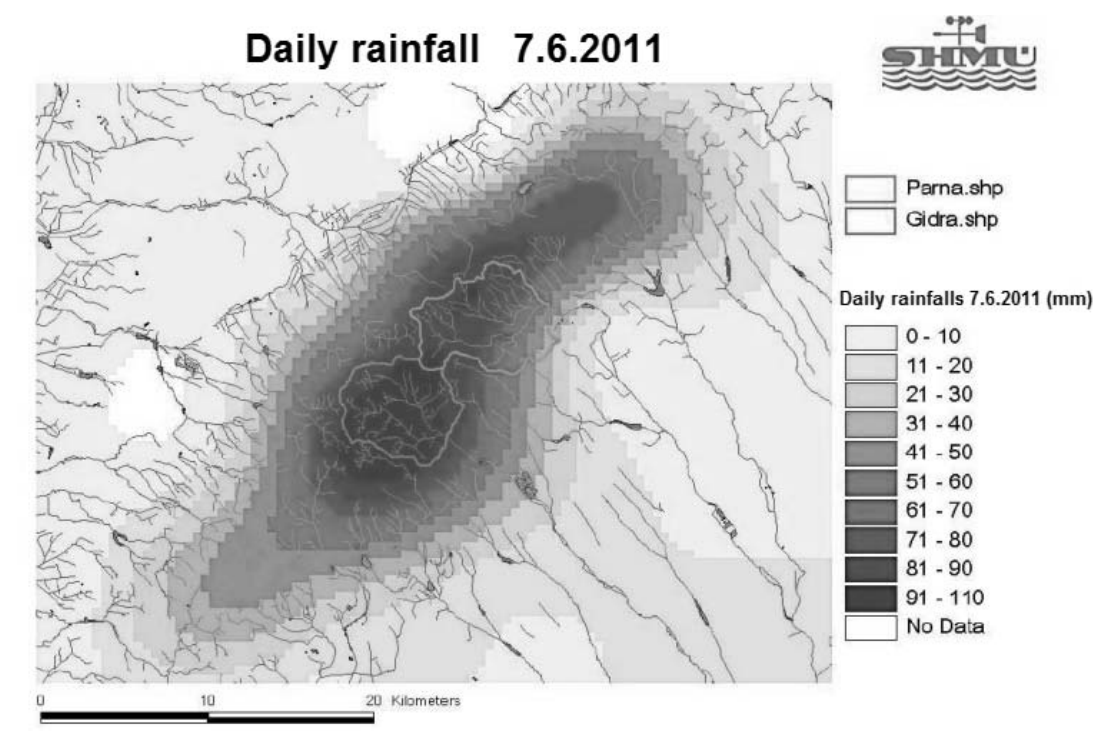

Fig. 4. Daily rainfall on June 7, 2011 [4] 
Enormous amount of rainfall that fell on the catchment area of the River Gidra in a very short time is typical of the High and Low Tatras mountain area, but not the Small Carpathians. Therefore, the meteorological situation was clearly the primary cause of the flash flood, and it significantly contributed to the destructiveness of the flood in the village of Píla.

\section{The shape of the river basin}

Each flash flood has its own peculiarities that reflect the local conditions of a basin. Empirical knowledge shows that from the same rainfall various amounts of runoff can be created. As it was mentioned above it depends on many factors.

A significant role in the formation and course of flash floods is mainly attributed to morphological parameters, like the shape of the river basin and the shape of the river site. They have a great impact on the concentration of the surface runoff and on its magnitude [6].

For river basins with a circular shape (Fig. 5), it is typical that water accumulates faster and in a short time period. That means the occurrence of a greater runoff than in the case of the longitudinal shape of a basin where the water flows to the main stream gradually, little by little [3]. As it is shown in Fig. 5, the River Gidra basin has a circular shape, so this factor was identified as one of the main factors for the formation of the flash flood in the village of Píla (2011). The combination of the extreme weather situation (rain, snow, snow melting, etc.) with the circular shape of a basin leads to the high probability of the occurrence of flash floods.
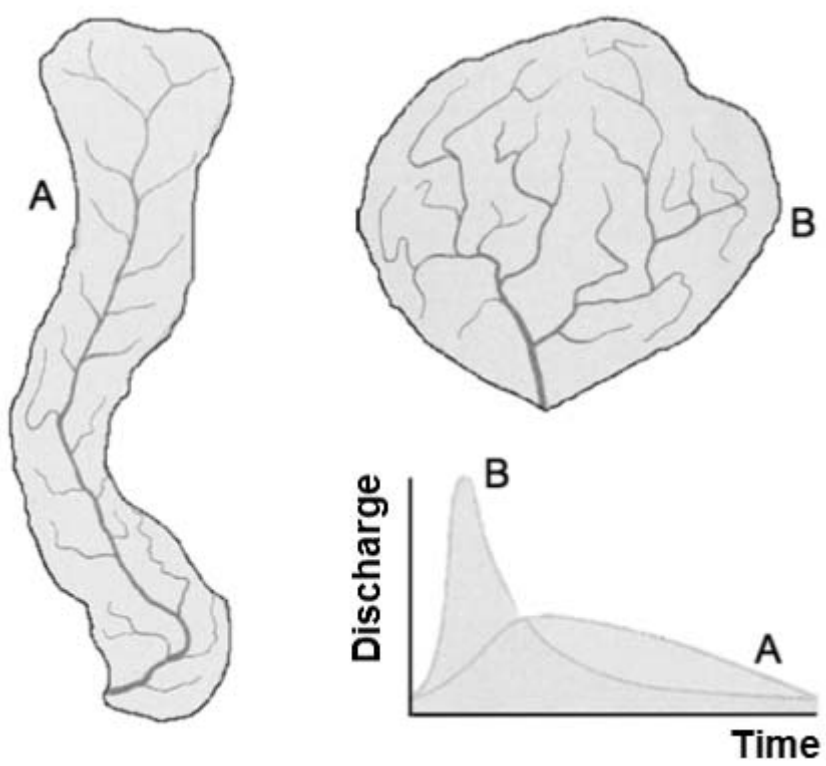

Fig. 5. Shapes of river basins [7] 


\section{Breakage of the barriers}

Acknowledging the diversity and variety of local conditions in a river basin and its physical and geographical characteristics is necessary for understanding flash floods as a hydrological response of especially small basins in an extreme meteorological situation [3]. It is also assumed that breaking of barriers affected the extent of the flash flood in the village of Píla. They have been naturally created through accumulation of river sediments on the fences (Fig. 6), which border the forest and swamp communities in the basin of the River Gidra (Fig. 7) during the extreme precipitation period.

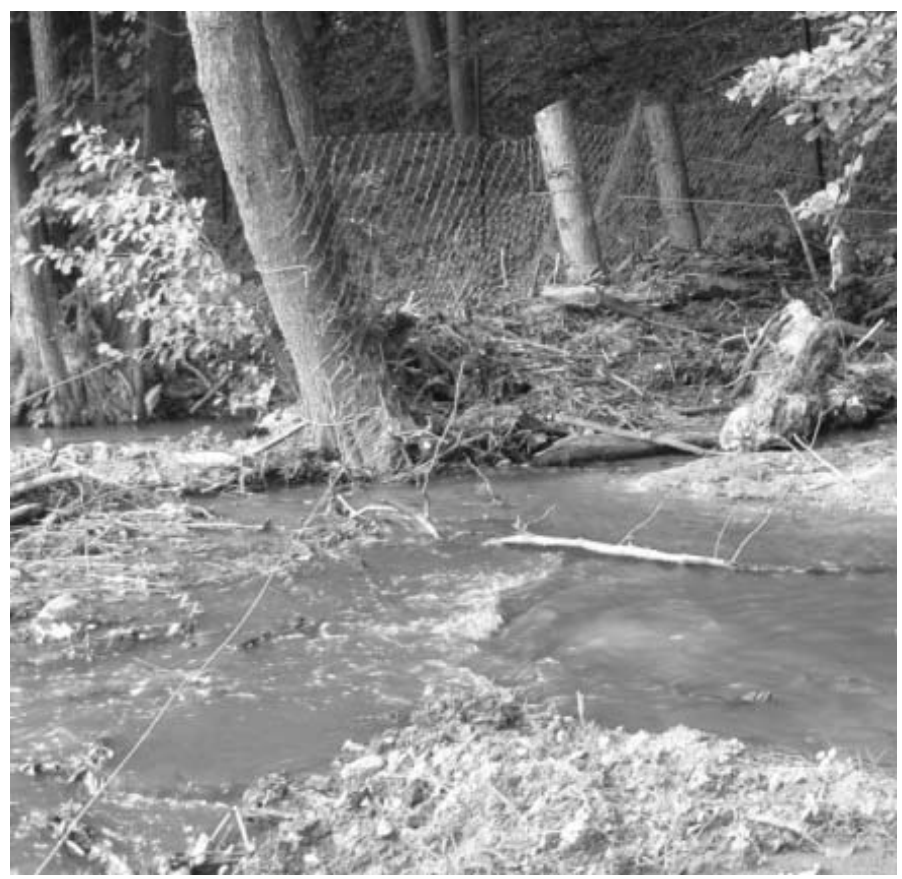

Fig. 6. Damaged fences

\section{Hydrological data}

After the evaluation of all the available morphology data about the River Gidra and surrounding terrain the second part of the field-research evaluation, which was focused on the hydrological data was proceeded. One gauging station is situated directly above the village of Píla (Fig. 8). So, after measuring the cross sections along the River Gidra, the field-research was focused on water level measurements in several cross-sections, as well.

The time course of the water levels is an essential input for setting up a numerical model of flood course observations [8]. During the field-research the velocities in the River Gidra were measured for determining the discharges. All the measured data were 
used as boundary conditions for the simulation of the unsteady surface flow in the HECRAS software simulation package.

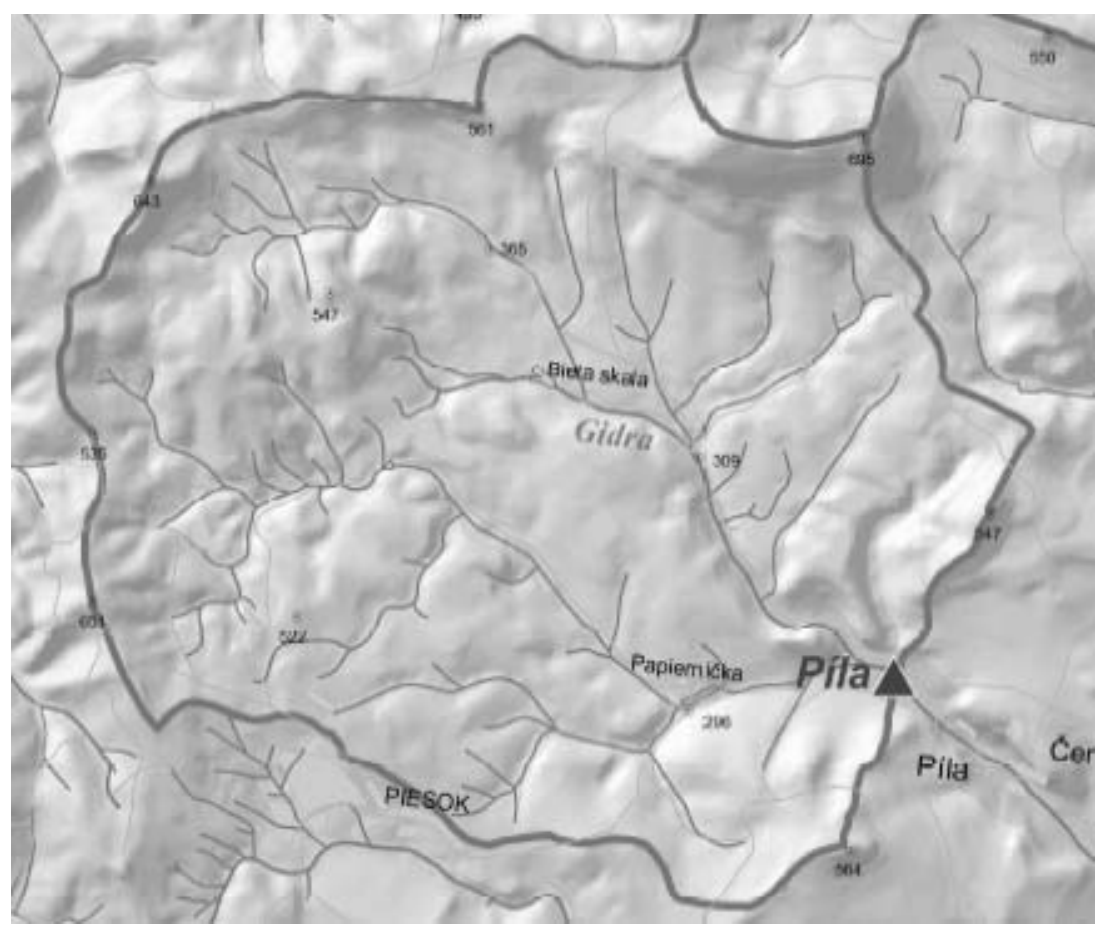

Fig. 7. Basin of the River Gidra [4]

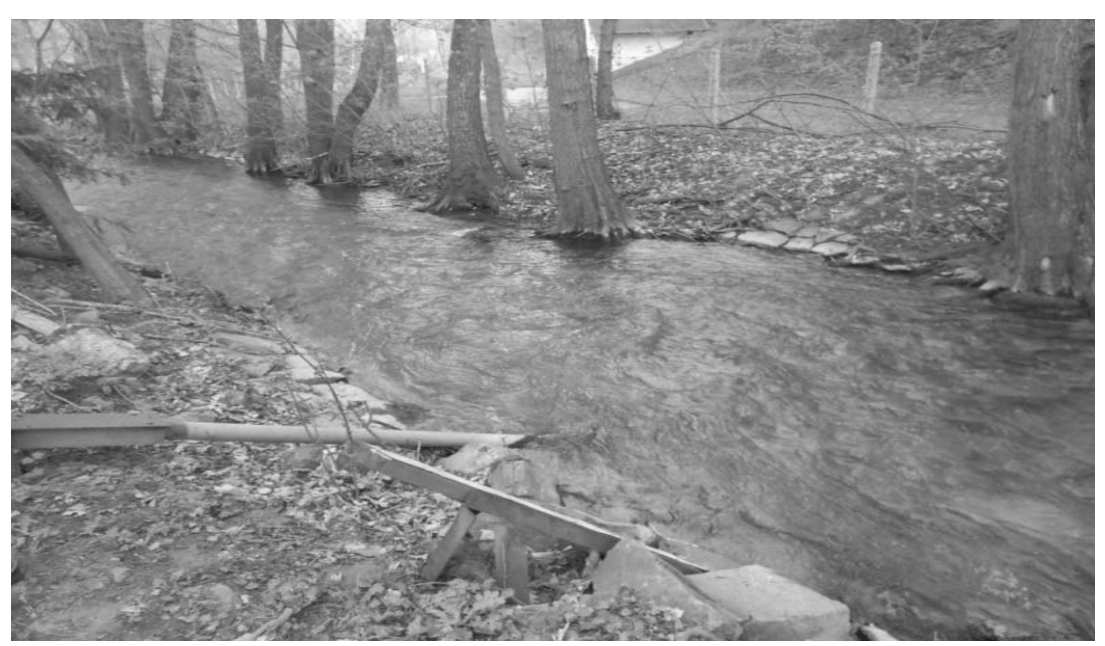

Fig. 8. The River Gidra at the gauging station site 
Flood marks can be seen on the houses and on the other private properties after the flood event. All of those flood marks were measured by the GNSS device. These data served in the simulation process for the calibration and verification purposes of the numerical model established during the flood. An example of a flood mark is shown in Fig. 9.

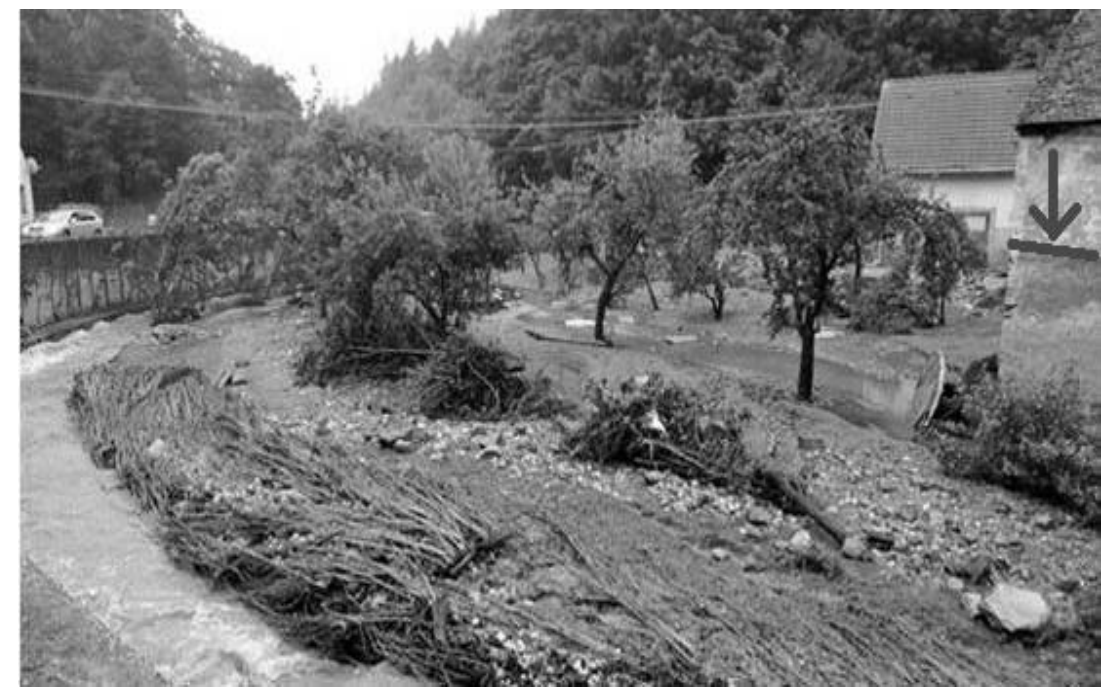

Fig. 9. Flood mark on an old house

\section{Modeling}

The HEC-RAS simulation package was used for the flood reconstruction [9]. The result of the unsteady river flow simulation was achieved after filling the model with all the necessary data (cross section profiles, roughness, possible barriers in the river, like fences and bridges, discharge, etc.). The results are shown in Fig. 10. The maximum flood level was verified by the flood marks (see legend).

The differences between the measured and calculated values could have been caused by various factors. Firstly, it is important to remember that for the unsteady open channel flow during the flood event, a 1D model was chosen. For this type of model it was quite complicated to specify the Manning roughness coefficient properly. The next problem was not taking into consideration the lateral inflow from the surrounding valley hill slopes. Finally, some mistakes could have appeared during the field-research, as well. In spite of those mistakes, the differences between the measured and the calculated values (Fig. 10) are sufficient and the model worked properly.

Only on two flood marks were differences between the measured and the calculated values greater than 2 meters. This could be due to the fact that these flood marks were actually located in the river bend and that the program did not calculate this situation properly. 


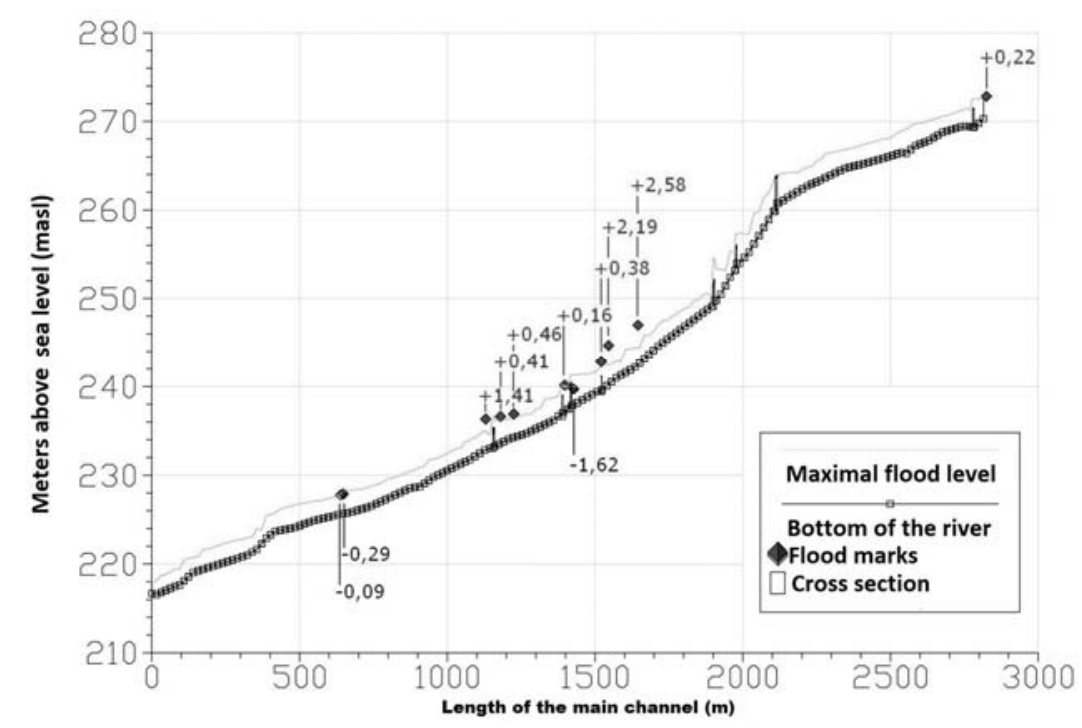

Fig. 10. Maximum water level during the flood

\section{Conclusion}

This paper deals with the simulation of an unsteady river flow in the River Gidra during a flood event. The field-research was performed to set up the model. It was focused on measuring cross section profiles, the surrounding terrain, river obstacles, water levels, etc. It was necessary to communicate with the mayor of the village and with other witnesses to get as much information about the flood as possible, as well. The results of the 1D river flow modeling are illustrated above. The graph represents the longitudinal profile of the measured flood marks and the calculated water levels of the River Gidra during the flood. Taking all the parameters, which could cause differences between the measured and the calculated values into consideration, the River Gidra model in the HEC-RAS simulation tool was set up properly and can be used for more flood forecasting calculations as well as for the creation of flood protection measures in the Small Carpathians region, especially in the Červený Kameň micro-region.

\section{Acknowledgment}

This article was developed on the basis of the financial support of the VEGA Agency project No. 1/1011/12. The field measurements were carried out under a program to encourage young researchers at the Slovak University of Technology in Bratislava while solving the project 'Field-research and data collection to determine the interaction of surface and groundwater in the Červený Kameň micro-region'. 


\section{References}

[1] Blahová A., Matoková K., Smrtník P., Faško P., Neštiak M., Hazlinger M. Flash flood on rivers in the Small Carpathians in June 2011, The Slovak Hydro-Meteorological Institute, Flood Report, (in Slovak) Bratislava, Slovakia, 2011.

[2] Kupčok S., Kováč V. Notes on ichthyofauna of the Gidra creek, Folia Faunistica Slovaca, Vol. 5, 2000, pp. 151-156.

[3] Grešková A. Analysis of chosen river basin parameters from flash flood occurrence point of view, (in Slovak), Geografický časopis, Vol. 2, 2005, pp. 131-144.

[4] Blaškovičová L., Poórová J., Hazlinger M., Tausberik O., Lupták L. Flash floods in Slovakia, Gidra and Parna Rivers, June 2011, (in Slovak) The Slovak HydroMeteorological Institute, Bratislava, Slovakia, 2011.

[5] http://www.vuvh.sk/download/ManazmentPovodi_rizik/zbornikPrispevkov/Konferencia/Pri spevky/SekciaC/ (last visited 2 February 2012).

[6] Smith K., Ward R. Floods: physical processes and human impacts; Chichester (Wiley), 1998.

[7] Schwarze R. Basis of hydrology, 3, The river basin, Lecture notes, Dresden, Technische Universität Dresden, Institut für Hydrologie und Meteorologie, 2007.

[8] Kádár I. Mobile flood protection walls, Pollack Periodica, Vol. 10. No.1, 2015, pp. 133-142.

[9] River Analysis System, HEC-RAS, User's Manual, Version 4.1. CA, U.S. Army Corps of Engineers Institute for water resources Hydrologic Engineering Centre, 2010. 